\title{
Effects of postpartum milking strategy on plasma mineral concentrations and colostrum, transition milk, and milk yield and composition in multiparous dairy cows
}

\author{
A. Valldecabres, ${ }^{1,2} \odot$ R. B. Lopes, ${ }^{1,2}$ A. Lago, ${ }^{3} \odot$ C. Blanc, ${ }^{4}$ and N. Silva-del-Río ${ }^{1,2 *}$ () \\ ${ }^{1}$ Veterinary Medicine Teaching and Research Center, University of California, Davis, Tulare 93274 \\ ${ }^{2}$ Department of Population Health and Reproduction, School of Veterinary Medicine, University of California, Davis 95616 \\ ${ }^{3}$ DairyExperts Inc., Tulare, CA 93274 \\ ${ }^{4}$ Lely Industries NV, Maasland, 3147, the Netherlands
}

\begin{abstract}
The effects of postpartum milking strategy on plasma mineral concentrations, blood $\beta$-hydroxybutyrate (BHB) concentration, and colostrum, transition milk, and first monthly test milk yield and composition were evaluated in 90 multiparous Jersey and Jersey $\times$ Holstein crossbreed cows from a commercial farm. Before first postpartum milking, cows were randomly assigned to the following milking strategies, implemented during the first $2 \mathrm{~d}$ postpartum: twice-a-day milking (M2, standard industry practice, milking every $12 \mathrm{~h} ; \mathrm{n}=$ 22), once-a-day milking (M1, milking every $24 \mathrm{~h}$; $\mathrm{n}=$ 24), restricted milking (MR, 3-L milking every $12 \mathrm{~h} ; \mathrm{n}$ $=21$ ), and delayed milking ( $\mathrm{MD}$, no milking for the first $24 \mathrm{~h}$, and milking every $12 \mathrm{~h}$ afterward; $\mathrm{n}=23$ ). Blood samples for total plasma $\mathrm{Ca}, \mathrm{P}$, and $\mathrm{Mg}$ determination were collected from enrollment every $4 \mathrm{~h}$ up to $48 \mathrm{~h}$, and at $3 \mathrm{~d}$ in milk. Blood BHB concentration was determined at 3 and $11 \mathrm{~d}$ in milk. Colostrum and transition milk yields were recorded, and samples were collected at each study milking for IgG and somatic cell count (SCC) determinations. Information for first monthly test milk yield and composition was obtained from the Dairy Herd Improvement Association. Statistical analyses were conducted using generalized multiple linear and Poisson regressions with Dunnett adjustment and M2 as reference group for mean comparisons. Overall, plasma $\mathrm{Ca}$ concentration within $48 \mathrm{~h}$ after enrollment was higher for MD $(2.17 \mathrm{mmol} / \mathrm{L})$, tended to be higher for MR $(2.15 \mathrm{mmol} / \mathrm{L})$, and was similar for M1 (2.09 mmol/L) compared with M2 cows (2.06 $\mathrm{mmol} / \mathrm{L})$. No statistically significant differences compared with M2 cows were observed for plasma $\mathrm{P}$ and $\mathrm{Mg}$ concentrations. Colostrum and transition milk and
\end{abstract}

Received April 10, 2021.

Accepted August 12, 2021.

*Corresponding author: nsilvadelrio@ucdavis.edu total $\mathrm{Ca}$ harvested within $48 \mathrm{~h}$ after enrollment were lower for M1, MR, and MD compared with M2 cows. The MD strategy prevented harvesting colostrum with $>50 \mathrm{~g}$ of $\operatorname{IgG} / \mathrm{L}$. No statistically significant effects were detected on plasma mineral concentrations at 3 DIM, blood BHB concentration, colostrum and transition milk SCC within $48 \mathrm{~h}$ after enrollment, or milk yield, energy-corrected milk yield, and SCC at first monthly test. Our results suggest that postpartum plasma Ca concentration may be influenced by postpartum milking strategy, without interfering with future milk yield and udder health. Further studies should evaluate whether the proposed milking strategies in early postpartum affect production, reproduction, or health.

Key words: calcium, colostrum, dairy cow, hypocalcemia, postpartum milking

\section{INTRODUCTION}

Lactation onset challenges dairy cows' ability to maintain energy and mineral balances. The uptake of minerals by the mammary gland is noteworthy; colostrum calcium $(\mathrm{Ca})$, phosphorus $(\mathrm{P})$, and magnesium $(\mathrm{Mg})$ concentrations can reach $2.2,1.6$, and $0.3 \mathrm{~g} / \mathrm{L}$, respectively (Tsioulpas et al., 2007). Consequently, the total amount of $\mathrm{Ca}$ harvested in $6 \mathrm{~L}$ of colostrum surpasses the estimated total $\mathrm{Ca}$ in plasma and extracellular fluid in a 600-kg cow (13 g of Ca; Goff, 2004), driving blood Ca concentration down around parturition. The nadir of blood Ca concentration is usually described as being within $48 \mathrm{~h}$ postpartum in multiparous cows (Kimura et al., 2006; Ramos-Nieves et al., 2009; Venjakob et al., 2019); afterward, blood Ca increases, although cases of low blood Ca at 3 or 4 DIM have also been described (Caixeta et al., 2017; Valldecabres et al., 2018; McArt and Neves, 2020). Low blood Ca concentration within $48 \mathrm{~h}$ postpartum has been associated with increased risk of disease and impaired reproductive performance (blood $\mathrm{Ca} \leq 1.90$ to $2.14 \mathrm{mmol} / \mathrm{L}$; Rodríguez et al., 
2017; Umaña Sedó et al., 2018; Valldecabres and Silvadel-Río, 2021a). Therefore, herd managers try to prevent this condition.

Anionic salts are used in the close-up diet to prevent hypocalcemia in $54.5 \%$ of large US dairies $(\geq 500$ cows; USDA-NAHMS, 2014). Nevertheless, although that strategy is successful at reducing the risk of clinical hypocalcemia (Santos et al., 2019), it may have a limited effect on subclinical hypocalcemia prevention (blood $\mathrm{Ca} \leq 2.12 \mathrm{mmol} / \mathrm{L}$ in $>44 \%$ of the cows; Brady, 2013; Martinez et al., 2016; Valldecabres and Silva-delRío, 2021b). Another common prophylactic strategy for hypocalcemia aims to increase peripartum $\mathrm{Ca}$ input through peripartum $\mathrm{Ca}$ supplementation by oral or i.v. administration (USDA-NAHMS, 2014). However, these supplements' effects on health, production, and reproduction are inconclusive, as performance varies widely among studies (Oetzel and Miller, 2012; Leno et al., 2018; Valldecabres and Silva-del-Río, 2021b). Thus, alternative prophylactic strategies for peripartum low Ca are needed.

Modified postpartum milking management strategies that limit the amount of colostrum and milk harvested after parturition have been considered as management strategies to improve postpartum energy balance and metabolic status (Lacasse et al., 2018). Nevertheless, few studies have evaluated blood minerals after the implementation of modified milking management strategies in multiparous Holstein cows (Loiselle et al., 2009; Carbonneau et al., 2012; Salgado-Hernández et al., 2014). Serum Ca and P concentrations were higher in multiparous cows milked once a day during the first week postpartum ( $\mathrm{n}=11$ cows/treatment; Loiselle et al., 2009), and a higher serum $P$ concentration was observed during the first $5 \mathrm{~d}$ postpartum under restricted milking in multiparous cows $(\mathrm{n}=16$ cows/treatment; Carbonneau et al., 2012). However, serum Ca, P, and $\mathrm{Mg}$ concentrations were not affected by restricted milking during the first day postpartum in the study by Salgado-Hernández et al. (2014; $\mathrm{n}=10$ cows/treatment). Limiting the amount of colostrum and milk harvested after parturition may have negative carryover effects on milk yield. For instance, cows milked once a day for periods of $1 \mathrm{wk}$ and longer had lower milk yield up to at least 10 wk postpartum (McNamara et al., 2008; Loiselle et al., 2009; Phyn et al., 2014).

We hypothesized that limiting the amount of colostrum and transition milk harvested during the first $2 \mathrm{~d}$ postpartum would reduce the usually observed decrease in blood Ca concentration. Hence, the objective of the present study was to evaluate the effects of 4 different postpartum milking strategies on plasma $\mathrm{Ca}$ concentration. In addition, plasma $\mathrm{P}$ and $\mathrm{Mg}$ concentrations, blood BHB concentration, and colostrum, transition milk, and first monthly test milk yield and composition were evaluated in 90 multiparous Jersey and Jersey $x$ Holstein crossbreed cows from a commercial farm.

\section{MATERIALS AND METHODS}

All procedures were approved by the University of California, Davis, Institutional Animal Care and Use Committee (no. 19799). Throughout this paper, mammary gland secretions harvested at first postpartum milking are referred as colostrum, and mammary gland secretions harvested at second, third, and fourth milkings are referred as transition milk.

\section{Study Herd Management}

The study was conducted in a commercial herd in California. The study herd milked 9,989 Jersey and Jersey $\times$ Holstein crossbreed cows twice a day in 2 double 60-stall herringbone parlors with an average 305-d mature-equivalent milk yield of 9,697 kg.

During the last $3 \mathrm{wk}$ of gestation, dry cows were moved to a close-up pen and offered once a day a TMR containing alfalfa hay, canola, corn silage, milo silage, rolled corn, and anionic salts. Cows calved in the closeup pen, and calves were separated from dams immediately after parturition. Colostrum was harvested in a double 10-stall herringbone parlor at the maternity area. Twice daily, recently calved cows were moved from the maternity pen to a fresh cow pen. Before being moved to a lactation pen, postpartum cows remained 30 $\mathrm{d}$ in the fresh cow pen, where farm personnel performed daily visual screenings for appetite and uterine disease. Clinical mastitis was diagnosed by farm personnel following the detection of abnormal milk secretion during regular forestripping. Postpartum cows were offered twice a day a TMR containing almond hulls, alfalfa hay, canola, corn silage, cotton seed, distillers dried grains, and rolled corn. Nutrient compositions of close-up and fresh cow TMR are presented in Table 1.

\section{Experimental Design}

A total of 90 multiparous Jersey and Jersey $\times$ Holstein crossbreed cows were enrolled in the study during 5 consecutive days (November 22-26, 2017); cows remained in the study for 1 mo after enrollment. Based on a pilot study (unpublished), a decrease of $0.25 \mathrm{mmol} / \mathrm{L}$ ( $\mathrm{SD}=$ $0.20 \mathrm{mmol} / \mathrm{L}$ ) in plasma Ca concentration after the second postpartum milking was anticipated. Because we expected (no data available) plasma Ca concentration to remain roughly constant after initial udder fill if no 


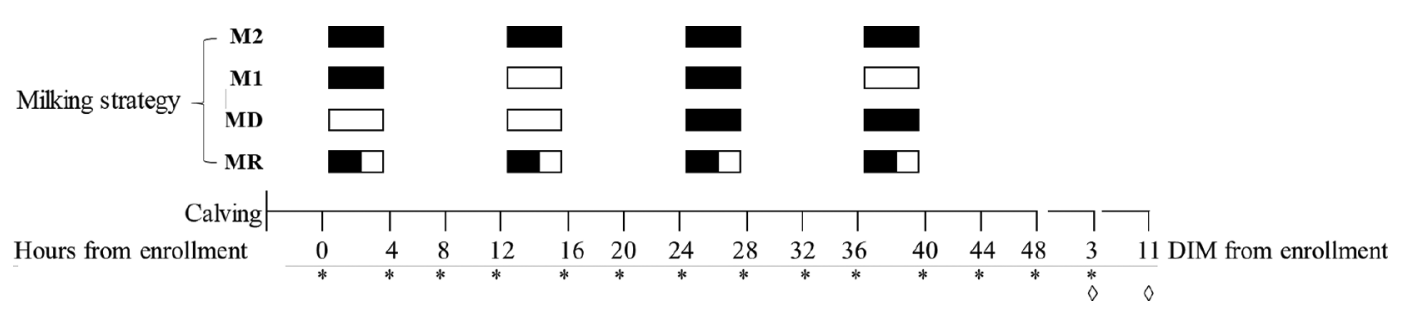

Figure 1. Study timeline for cows assigned to 4 different milking strategies during the first $48 \mathrm{~h}$ postpartum: M2 (4 milkings $12 \mathrm{~h}$ apart); M1 (2 milkings $24 \mathrm{~h}$ apart); MR ( 4 milkings $12 \mathrm{~h}$ apart; $3 \mathrm{~L} /$ milking); or MD (2 milkings $12 \mathrm{~h}$ apart starting at $24 \mathrm{~h}$ after enrollment). Milkings are represented in bars: black bars represent complete milkings, blank bars represent no milking, and half-black, half-blank bars represent milking limited to $3 \mathrm{~L}$. ${ }^{*}$ Blood samples for $\mathrm{Ca}, \mathrm{P}$, and $\mathrm{Mg}$ were collected at 4-h intervals from 0 to $48 \mathrm{~h}$ postpartum, and at $3 \mathrm{DIM}$. $\diamond \mathrm{Blood}$ samples for BHB were collected at 3 and 11 DIM.

colostrum and transition milk were harvested, 15 cows per group were required to detect differences in plasma Ca concentration after the second postpartum milking $(\alpha=0.05 ; \beta=0.10)$. The study evaluated 4 milking strategies implemented during the first $2 \mathrm{~d}$ postpartum. Twice a day, multiparous fresh cows housed in the study herd maternity area were randomly assigned to 1 of the 4 milking strategies before first postpartum milking using a random number generator (rand function, Excel 2010, Microsoft Corp.). The milking strategies were as follows: twice-a-day milking [M2; milking every $12 \mathrm{~h}$ (standard industry practice); $\mathrm{n}=22$ ], once-a-day milking [M1; milking every $24 \mathrm{~h}$ (allows for colostrum harvest while reducing total $\mathrm{Ca}$ output and labor); $\mathrm{n}$ $=24]$, restricted milking $[\mathbf{M R}$; 3-L milking every 12 $\mathrm{h}$ (allows for some colostrum harvest while reducing the total $\mathrm{Ca}$ output and maintaining milking frequency, but demands more attention in the milking parlor); $\mathrm{n}$ $=21]$, and delayed milking [MD; no milking for the

Table 1. Nutrient composition (\%, unless otherwise noted) of close-up and fresh cow diets

\begin{tabular}{|c|c|c|}
\hline Nutrient composition $^{1}$ (DM basis) & Close-up & Fresh \\
\hline $\mathrm{CP}$ & 15.70 & 17.70 \\
\hline Crude fat & 2.31 & 4.88 \\
\hline $\mathrm{ADF}$ & 24.70 & 19.60 \\
\hline NDF & 33.30 & 28.90 \\
\hline Lignin & 5.31 & 5.67 \\
\hline Starch & 17.00 & 19.10 \\
\hline Ash & 12.59 & 9.33 \\
\hline Calcium & 2.69 & 1.03 \\
\hline Phosphorus & 0.44 & 0.68 \\
\hline Magnesium & 0.59 & 0.33 \\
\hline Potassium & 1.72 & 2.38 \\
\hline Sulfur & 0.48 & 0.28 \\
\hline Sodium & 0.39 & 0.50 \\
\hline Chloride & 1.69 & 0.76 \\
\hline $\mathrm{DCAD}^{2}(\mathrm{mEq} / 100 \mathrm{~g})$ & -16.20 & 43.60 \\
\hline
\end{tabular}

${ }^{1}$ Wet chemistry analysis (Cumberland Valley Analytical Services, Hagerstown, MD).

${ }^{2} \mathrm{DCAD}$ calculations were performed according to the following equation: DCAD $(\mathrm{mEq} / 100 \mathrm{~g})=[(\mathrm{Na}+\mathrm{K})-(\mathrm{Cl}+\mathrm{S})]$. first $24 \mathrm{~h}$, and milking every $12 \mathrm{~h}$ afterward (negative control, to evaluate the effects of no milking for $24 \mathrm{~h}$ postpartum); $\mathrm{n}=23$. Hence, M1 and MD cows were milked twice and M2 and MR cows were milked 4 times during the first $2 \mathrm{~d}$ postpartum (Figure 1).

Immediately after parturition, enrolled cows were moved into a dry-lot pen fitted with 40 headlocks on the feed bunk line and adjacent to the maternity milking parlor. At milking time, cows were sorted according to the assigned milking strategy and moved to the maternity milking parlor. The milking routine involved pre-dipping and post-dipping using a teat disinfectant solution, and manual forestripping after pre-dipping to evaluate abnormal milk. Researchers milked study cows directly into graded clear bucket milkers. Cows remained in this pen up to $48 \mathrm{~h}$ after enrollment (study intensive sampling period). Then cows were moved to the fresh cow pen as described previously. Cows had access to ad libitum fresh cow TMR and water (Table 1). Farm employees performed daily health checks to the cows enrolled in the study while in the maternity pen and fresh cow pen, according to the herd management protocol previously described.

\section{Data Collection}

Colostrum and transition milk yields were recorded using graded clear buckets before manual homogenization and sample collection. If yield was $<3 \mathrm{~L}$ (lowest volume measured by the bucket scale), a portable digital scale was used to determine colostrum or transition milk yield (Ship-Elite, American Weight Scales Inc.). First monthly test milk yield and SCC information was obtained from the DHIA (AgriTech Analytics, Visalia, CA).

A single researcher scored cows for body condition at enrollment, using a 1 to 5 scale with 0.25 -unit increments (Ferguson et al., 1994). Calving time was obtained from on-farm records. Information regarding parity and breed was obtained from the herd manage- 
ment software (DairyComp305; Valley Agricultural Software).

\section{Sample Collection and Laboratory Analyses}

Blood samples for total $\mathrm{Ca}, \mathrm{P}$, and $\mathrm{Mg}$ determination were collected from the coccygeal vessels using an evacuated tube coated with heparin (BD Vacutainer, Becton Dickinson) starting before first postpartum milking (enrollment; 8 h 26 min \pm 4 h 3 min after calving; mean \pm SD) every $4 \mathrm{~h}$ up to $48 \mathrm{~h}$ after enrollment, and at 3 DIM (Figure 1). Cows were moved to the feed bunk line headlocks for blood sample collection. Samples collected at 3 DIM were obtained in the fresh cow pen during the daily health evaluations. Given the sampling frequency, if no blood was drawn in 2 consecutive venipunctures, no further attempts were made until the next sampling time, to prevent vessel damage and hematoma formation. After drawing blood, the samples were centrifuged at $1,430 \times g$ for 15 min at room temperature, and the plasma was harvested and stored on the farm at $-18^{\circ} \mathrm{C}$. Once a day, the processed samples were transported to the laboratory in insulated boxes and stored at $-20^{\circ} \mathrm{C}$ until analysis. Frozen plasma samples were shipped to the California Animal Health and Food Safety Lab (University of California, Davis) for total $\mathrm{Ca}, \mathrm{P}$, and $\mathrm{Mg}$ determination by inductively coupled plasma-optical emission spectrometry (Melton et al., 1990). The intra- and interassay coefficients of variation $(\mathrm{CV})$ were 2.0 and $4.4 \%$ for $\mathrm{Ca}, 2.2$ and $3.7 \%$ for $\mathrm{P}$, and 2.3 and $3.5 \%$ for $\mathrm{Mg}$.

Blood samples for BHB determination were collected from the coccygeal vessels using a heparin-coated evacuated tube (BD Vacutainer, Becton Dickinson) at 3 and 11 DIM during the daily farm check for health disorders (Figure 1). After collection, samples were placed into a refrigerator at $4^{\circ} \mathrm{C}$ until analyses. Within $1 \mathrm{~h}$ after collection, the samples were homogenized using a tube rocker, and BHB was determined using a hand-held meter (BHBCheck, PortaCheck; Sailer et al., 2018).

Colostrum and transition milk samples were collected after each milking from the bucket milkers after previous manual homogenization. Milk samples were stored on farm at $-18^{\circ} \mathrm{C}$, and once daily they were transported to the laboratory, where they were stored at $-20^{\circ} \mathrm{C}$. Upon on-farm study completion, the frozen milk samples were thawed, homogenized using a tube rocker, and transferred into duplicated smaller containers. Colostrum and transition milk samples were then submitted to the California Animal Health and Food Safety Lab (University of California, Davis) for IgG and total $\mathrm{Ca}$ determination by radial immunodiffusion (intra-assay $\mathrm{CV}=4.8 \%$; Bovine IgG RID kit, Triple $\mathrm{J}$
Farms) and inductively coupled plasma-optical emission spectrometry (intra-assay $\mathrm{CV}=10 \%$; interassay $\mathrm{CV}=6 \%$; Melton et al., 1990), respectively. Colostrum and transition milk SCC were determined in the laboratory from the remaining samples using a somatic cell counter (DeLaval Cell Counter, DeLaval International $\mathrm{AB})$.

\section{Statistical Analyses}

All statistical analyses were performed with SAS (version 9.4, SAS Institute Inc.). Evaluated study outcomes include plasma mineral concentrations, blood BHB concentration, colostrum and transition milk yield and composition (IgG and SCC), and first monthly test milk yield, ECM yield, and SCC. Baseline comparison of cows enrolled in the 4 milking strategies was performed using ANOVA, chi-squared, or Fisher's exact test with the ANOVA and FREQ procedures. Significance was declared at $P \leq 0.05$ and trends at $0.05<P \leq 0.10$ for all results. The accompanying figures were created using SigmaPlot (version 14.0, Systat Software Inc.).

Plasma Mineral Concentrations. Multiple linear regression was used to evaluate the plasma $\mathrm{Ca}, \mathrm{P}$, and Mg concentrations, using the MIXED procedure. Given the study design, separate analyses were conducted for the first $48 \mathrm{~h}$ after enrollment (study milking strategies implementation period) and 3 DIM (cows had been milked following herd management practices). The models included the fixed effects of milking strategy (M2, M1, MR, and MD), breed (Jersey and Jersey $\times$ Holstein crossbreed), and parity (second, third, and $\geq$ fourth) considered beforehand for importance and potential confounders for the evaluated outcomes and retained in the models regardless of the $P$-value. In addition, time relative to enrollment as a categorical variable (h $4,8,12,16,20,24,28,32,36,40,44$, and 48) was included with the same criteria in the $48 \mathrm{~h}$ postenrollment models. In that case, the repeated statement included cow as the subject and the autoregressive 1 variance-covariance structure. Plasma mineral baseline concentration was considered in the models as continuous $(\mathrm{P}$ and $\mathrm{Mg})$ or binary variable $(\mathrm{Ca})$ and removed at $P>0.05$. Plasma Ca binary variable was defined based on the $2.12 \mathrm{mmol} / \mathrm{L}$ threshold commonly used for definition of low blood Ca $(8.5 \mathrm{mg} / \mathrm{dL}$; Martinez et al., 2012; Oetzel, 2013; Valldecabres et al., 2018). This approach was followed to minimize the previously reported collinearity between plasma Ca concentration and parity (Neves et al., 2017; Saborío-Montero et al., 2017; Valldecabres et al., 2019); in our study it showed a moderate correlation (Spearman's $\rho=-0.38$ ). Other effects evaluated and removed from the models at $P$ $>0.05$ include calving to enrollment interval (h); and 
interactions of milking strategy with breed, parity, plasma mineral concentrations at enrollment, and time. Denominator degrees of freedom were calculated using the Kenward-Roger method. The association between milking strategy and plasma minerals concentration was quantified with least squares means (LSM) and standard error of the mean (SEM), using the lsmeans statement and Dunnett adjustment with M2 as the reference group to protect mean comparisons from type I error. One observation at $12 \mathrm{~h}$ after enrollment was identified as influential based on the studentized residuals $(>|4|)$ for the plasma Ca concentration model and removed from the analyses. The homoscedasticity and independence of errors assumption was assessed with the final models' residuals plots.

Plasma Ca concentration nadir and time at its observation were identified for each cow and evaluated using multiple linear regression as described earlier for the plasma mineral concentrations at 3 DIM. Low plasma Ca concentration, defined as $\leq 2.12 \mathrm{mmol} / \mathrm{L}$ within 48 $\mathrm{h}$ after enrollment, was evaluated using multiple Poisson regression with the GENMOD procedure and log link function. The model was built as described for the plasma mineral concentrations. The lsmeans statement with Dunnett adjustment and the exp option was used to quantify the association between low plasma $\mathrm{Ca}$ concentration and milking strategy, and to obtain the risk ratio and Wald 95\% CI associated with each milking strategy for low plasma Ca concentration, with M2 cows as the reference group. The risk ratio represents the ratio of the probability of low plasma Ca concentration for M1, MR, and MD cows, to the probability of low plasma Ca concentration for M2 cows. Overall model fit was assessed with the goodness-of-fit chisquared test. Descriptive statistics of the proportion of cows with low plasma Ca concentration at 3 DIM was calculated with the MEANS procedure.

Blood BHB Concentration and Hyperketonemia. Multiple linear regression was used to evaluate blood BHB concentration using the MIXED procedure. To comply with the assumption of homoscedasticity of residuals, blood BHB data were $\log _{10}$ transformed; for this outcome, LSM and SEM were estimated from untransformed data, whereas $P$-values reflect statistical analysis of transformed data. The model was built as described for plasma mineral concentrations. Time was defined as 3 and 11 DIM, and the repeated statement included cow as the subject and the unstructured variance-covariance structure. Overall model fit was assessed evaluating the final model residuals plots generated with the residual option of the model statement. Descriptive statistics of the proportion of cows with hyperketonemia (blood BHB $\geq 1.2 \mathrm{mmol} / \mathrm{L}$; Sailer et al., 2018) was calculated with the MEANS procedure.
Colostrum and Transition Milk Yield and Composition. Multiple linear regression was used to evaluate colostrum and transition milk yield and composition using the MIXED procedure. Yields of colostrum, transition milk, and $\mathrm{Ca}$ were analyzed as totals and as repeated measures (outputs associated with $0-24$ and $>24-48 \mathrm{~h}$ after enrollment). In the former, time was defined as a categorical variable (0-24, $>24-48 \mathrm{~h}$ after enrollment), and the repeated statement included cow as the subject and the unstructured variance-covariance structure. Concentrations of $\operatorname{IgG}$ were analyzed separately for each postpartum milking number, and SCC as the average of all postpartum milkings within $48 \mathrm{~h}$ after enrollment. Before analysis, SCC data were transformed to comply with the assumption of homoscedasticity of residuals as described for blood BHB. Models were built as described for plasma minerals without the consideration of baseline plasma mineral concentrations.

Milk Yield and Composition at First Monthly Test. Multiple linear regression was used to evaluate milk yield and composition at first monthly test using the MIXED procedure. Yield of ECM was calculated as $($ milk yield $\times 0.327)+($ milk fat yield $\times 12.95)+($ milk protein yield $\times 7.20$ ). Models were built as described for plasma mineral concentrations without the consideration of baseline plasma mineral concentrations; also, DIM at first monthly test was offered to the model and removed at $P>0.05$. Before data analysis, SCC data were transformed and are presented as described in the "Blood BHB" section.

\section{RESULTS}

Of the total 90 multiparous cows enrolled in the study, 46 were Jersey and 44 Jersey $\times$ Holstein crossbreed cows. Seven cows were excluded from the study due to severe lameness (MD: $\mathrm{n}=1$ ), treatment by farm personnel for retained placenta $(\mathrm{M} 2: \mathrm{n}=1)$ or digestive disorder (MR: $\mathrm{n}=1$ ) within $48 \mathrm{~h}$ following enrollment, and protocol deviation [missed milking (MR: $\mathrm{n}=1$; MD: $\mathrm{n}=2$ ) or additional milking (MD: $\mathrm{n}=1)]$. Thus, the total number of cows included in the data analysis was 83 (M2: $\mathrm{n}=21$; M1: $\mathrm{n}=24$; MR: $\mathrm{n}=19$; MD: $\mathrm{n}$ $=19$ ). Characteristics of cows included in the analyses are summarized in Table 2. Distributions of plasma Ca, $\mathrm{P}$, and $\mathrm{Mg}$ concentrations at enrollment were similar between milking strategies (Figure 2). On average, the calving to first postpartum milking interval was $9 \mathrm{~h}$ $36 \mathrm{~min} \pm 3 \mathrm{~h} 11 \mathrm{~min}$ for M2 cows, $10 \mathrm{~h} 30 \mathrm{~min} \pm 4 \mathrm{~h}$ 15 min for M 1 cows, 8 h 36 min \pm 3 h 48 min for MR cows, and $32 \mathrm{~h} 58 \mathrm{~min} \pm 3 \mathrm{~h} 44 \mathrm{~min}$ for MD cows, respectively (mean $\pm \mathrm{SD}$ ). Once milking was initiated, the average milking interval was $11 \mathrm{~h} 35 \mathrm{~min}$ for M2 
Table 2. Descriptive statistics of cow-level variables describing multiparous Jersey and Jersey $\times$ Holstein crossbreed cows included in the study, by milking strategy

\begin{tabular}{|c|c|c|c|c|c|}
\hline \multirow[b]{2}{*}{ Variable } & \multicolumn{4}{|c|}{ Milking strategy $^{1}$} & \multirow[b]{2}{*}{$P$-value } \\
\hline & M2 & M1 & MR & $\mathrm{MD}$ & \\
\hline Cows (n) & 21 & 24 & 19 & 19 & \\
\hline Parity (\%) & & & & & 0.67 \\
\hline Second & 28.6 & 27.3 & 42.1 & 44.4 & \\
\hline Third & 33.3 & 22.7 & 21.1 & 11.1 & \\
\hline$\geq$ Fourth & 38.1 & 50.0 & 36.8 & 44.5 & \\
\hline BCS at calving (\%) & & & & & 0.81 \\
\hline$\leq 2.50$ & 27.8 & 21.0 & 16.7 & 11.8 & \\
\hline $2.75-3.25$ & 66.7 & 63.2 & 61.1 & 70.6 & \\
\hline$\geq 3.50$ & 5.5 & 15.8 & 22.2 & 17.6 & \\
\hline Jersey $\times$ Holstein crossbreed $(\%)$ & 40.0 & 52.4 & 42.1 & 61.1 & 0.54 \\
\hline
\end{tabular}

${ }^{1}$ Within $48 \mathrm{~h}$ after enrollment for cows milked 4 times $12 \mathrm{~h}$ apart (M2), twice $24 \mathrm{~h}$ apart (M1), 4 times $12 \mathrm{~h}$ apart (3 L/milking; MR), or twice $12 \mathrm{~h}$ apart starting at $24 \mathrm{~h}$ after enrollment (MD).

and MR, $23 \mathrm{~h} 48$ min for M1, and 12 h 18 min for MD cows during the study period.

\section{Plasma Mineral Concentrations}

Calcium. Overall, milking strategy was associated with plasma Ca concentration within $48 \mathrm{~h}$ af-

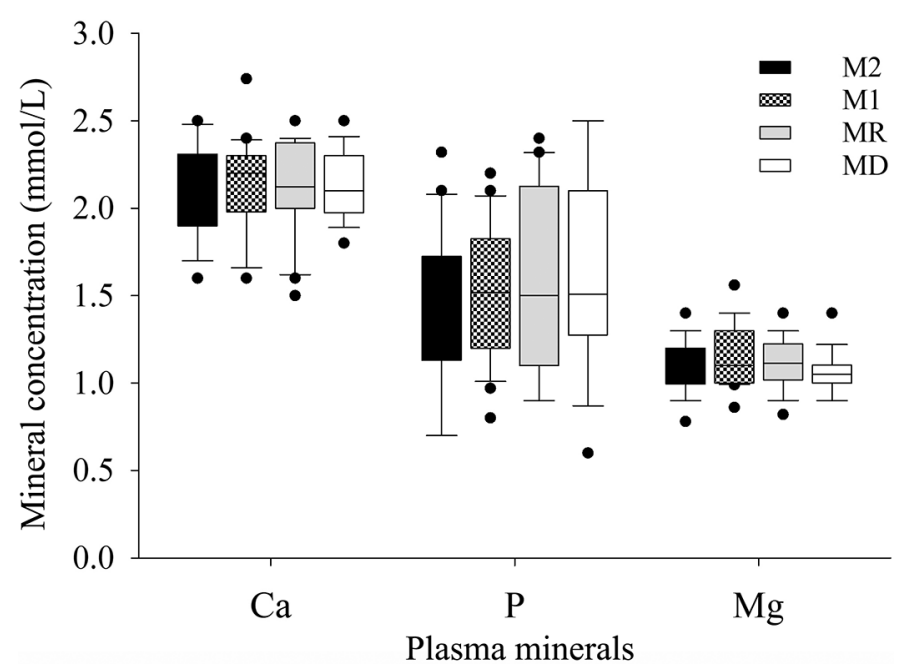

Figure 2. Box-and-whisker plots of plasma calcium (Ca), phosphorus $(\mathrm{P})$, and magnesium $(\mathrm{Mg})$ concentrations $(\mathrm{mmol} / \mathrm{L})$ at enrollment (8 h 26 min \pm 4 h 3 min after calving; mean \pm SD) for multiparous Jersey and Jersey $\times$ Holstein crossbreed cows assigned to 1 of 4 milking strategies from 0 to $48 \mathrm{~h}$ after enrollment: M2 $(4$ milkings $12 \mathrm{~h}$ apart; $\mathrm{n}=21)$, M1 (2 milkings $24 \mathrm{~h}$ apart; $\mathrm{n}=24)$, MR (4 milkings 12 $\mathrm{h}$ apart; $3 \mathrm{~L} /$ milking; $\mathrm{n}=19)$, or MD (2 milkings $12 \mathrm{~h}$ apart starting at $24 \mathrm{~h}$ after enrollment; $\mathrm{n}=19$ ). In the box plots, the boundaries of the box closest to and farthest from the horizontal axis indicate the 25th and 75th percentiles, respectively; the line within the box indicates the median; whiskers above and below the box indicate the 10th and 90th percentiles; and points above and below the whiskers indicate observations outside the 10th and 90th percentiles, respectively. Plasma $\mathrm{Ca}, \mathrm{P}$, and $\mathrm{Mg}$ concentrations were similar between treatments $(P=0.99,0.72$, and 0.37 , respectively $)$. ter enrollment $(P=0.04$; Figure 3$)$. Using M2 cows as reference $(2.06 \pm 0.03 \mathrm{mmol} / \mathrm{L})$, plasma $\mathrm{Ca}$ was higher for MD cows $(2.17 \pm 0.03 \mathrm{mmol} / \mathrm{L} ; P=0.04)$ and tended to be higher for MR cows $(2.15 \pm 0.03$ $\mathrm{mmol} / \mathrm{L} ; \quad P=0.08)$. No statistically significant differences were observed between M2 and M1 cows $(2.08 \pm 0.03 \mathrm{mmol} / \mathrm{L} ; P=0.88)$. Additional effects included in the model were breed $(P=0.25)$, parity $(P<0.001)$, plasma $\mathrm{Ca}$ at enrollment $(P<0.001)$, and time $(P=0.05)$. No significant treatment by time effects were observed $(P=0.78$; Supplemental Figure S1, https://escholarship.org/uc/item/2ht139cf). At 3 DIM, M2 plasma Ca concentration $(2.14 \pm 0.08$ $\mathrm{mmol} / \mathrm{L})$ was similar $(P=0.62)$ to $\mathrm{M} 1(2.28 \pm 0.07$ $\mathrm{mmol} / \mathrm{L}), \mathrm{MR}(2.23 \pm 0.07 \mathrm{mmol} / \mathrm{L})$, and MD (2.20 \pm $0.08 \mathrm{mmol} / \mathrm{L})$ cows, when accounting for the effects of breed $(P=0.22)$ and parity $(P=0.83)$.

The nadir of plasma Ca concentration and time of its observation within $48 \mathrm{~h}$ after enrollment were similar for $\mathrm{M} 2(1.81 \pm 0.05 \mathrm{mmol} / \mathrm{L}$ at $27.7 \pm 4.0 \mathrm{~h})$, M1 $(1.80 \pm 0.05 \mathrm{mmol} / \mathrm{L}$ at $19.9 \pm 3.9 \mathrm{~h}), \mathrm{MR}(1.85 \pm$ $0.06 \mathrm{mmol} / \mathrm{L}$ at $32.2 \pm 4.1 \mathrm{~h}$ ), and MD cows (1.92 \pm $0.06 \mathrm{mmol} / \mathrm{L}$ at $30.8 \pm 4.4 \mathrm{~h})$. Effects included in the nadir of plasma $\mathrm{Ca}$ concentration model were milking strategy $(P=0.46)$, breed $(P=0.73)$, parity $(P=$ $0.06)$, and plasma Ca at enrollment $(P=0.009)$. Effects included in the time of nadir observation model were milking strategy $(P=0.14)$, breed $(P=0.22)$, parity $(P=0.88)$, and plasma Ca at enrollment $(P=0.005)$.

Low plasma Ca concentration $(\leq 2.12 \mathrm{mmol} / \mathrm{L})$ tended to be associated with the milking strategy within $48 \mathrm{~h}$ after enrollment $(P=0.06$; Figure 4$)$. Compared with M2 cows, the risk of low Ca within $48 \mathrm{~h}$ following enrollment tended to be $34 \%$ lower for MD cows [risk ratio $(95 \% \mathrm{CI})=0.66(0.43-1.02)]$, and was similar for M1 [risk ratio $=0.96(0.66-1.39)$ ] and MR cows [risk ratio $=0.77(0.47-1.26)]$, accounting for the effects of 

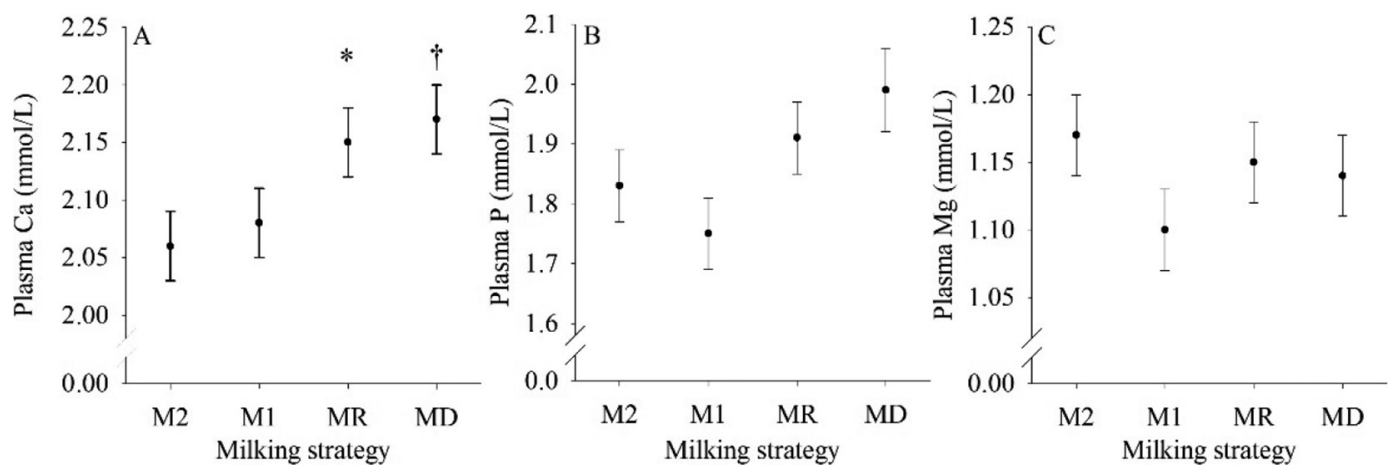

Figure 3. Milking strategy effect (LSM $\pm \mathrm{SEM})$ on plasma calcium $(\mathrm{Ca} ; P=0.04)$, phosphorus $(\mathrm{P} ; P=0.04)$, and magnesium concentrations $(\mathrm{Mg} ; P=0.22)$ within $48 \mathrm{~h}$ after enrollment for multiparous Jersey and Jersey $\times$ Holstein crossbreed cows assigned to M2 (4 milkings 12 $\mathrm{h}$ apart; $\mathrm{n}=21)$, M1 (2 milkings $24 \mathrm{~h}$ apart; $\mathrm{n}=24)$, MR (4 milkings $12 \mathrm{~h}$ apart; $3 \mathrm{~L} /$ milking; $\mathrm{n}=19)$, or MD (2 milkings $12 \mathrm{~h}$ apart starting at $24 \mathrm{~h}$ after enrollment; $\mathrm{n}=19)$. ${ }^{*} \dagger$ Differences compared with $\mathrm{M} 2$ cows at ${ }^{*} P<0.10$ and $\dagger P \leq 0.05$. Additional effects were as follows: in the Ca model, breed $(P=0.25)$, parity $(P<0.001)$, plasma Ca at enrollment $(P<0.001)$, and time $(P=0.05)$; in the $\mathrm{P}$ model, breed $(P=0.76)$, parity $(P=0.24)$, plasma $\mathrm{P}$ at enrollment $(P=0.003)$, and time $(P=0.30)$; and in the $\mathrm{Mg}$ model, breed $(P=0.12)$, parity $(P=0.04)$, plasma $\mathrm{Mg}$ at enrollment $(P<0.001)$, time $(P=0.03)$, and calving-to-enrollment interval $(P=0.04)$.

breed $(P=0.41)$, parity $(P=0.009)$, low plasma Ca at enrollment $(P=0.004)$, and time $(P=0.43)$. At 3 DIM the proportions of cows with low plasma Ca concentration were $46.7 \%$ (M2), $16.2 \%$ (M1), $30.2 \%$ (MR), and $22.3 \%$ (MD).

Phosphorus. Overall, milking strategy was associated with plasma $\mathrm{P}$ concentration within $48 \mathrm{~h}$ after enrollment $(P=0.04$; Figure 3$)$. Nevertheless, compared with $\mathrm{M} 2$ cows $(1.83 \pm 0.06 \mathrm{mmol} / \mathrm{L})$ plasma $\mathrm{P}$ concentration was similar for M1 $(1.75 \pm 0.06 \mathrm{mmol} / \mathrm{L}$; $P=0.68), \mathrm{MR}(1.91 \pm 0.06 \mathrm{mmol} / \mathrm{L} ; P=0.64)$, and

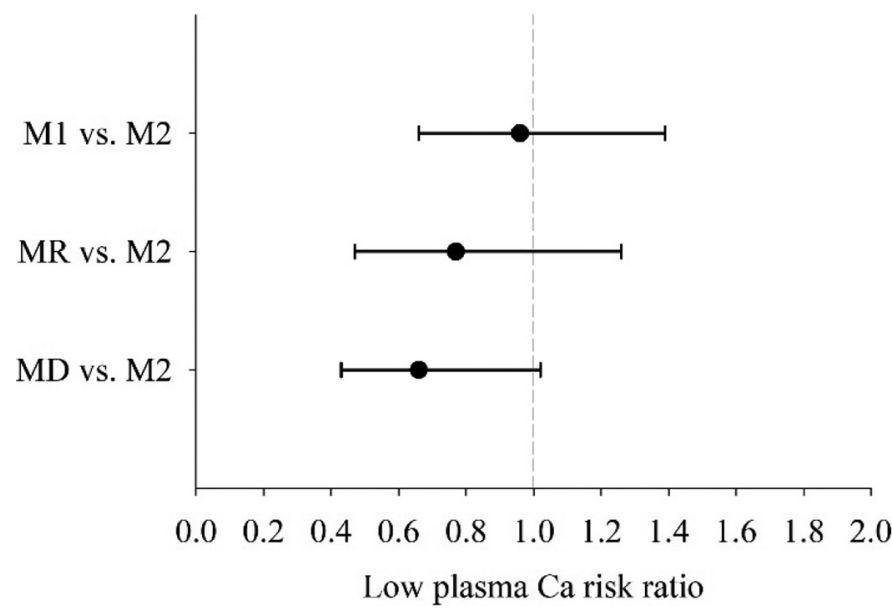

Figure 4. Risk ratio for low plasma calcium $(\mathrm{Ca} \leq 2.12 \mathrm{mmol} / \mathrm{L})$ within $48 \mathrm{~h}$ after enrollment for multiparous Jersey and Jersey $\times$ Holstein crossbreed cows assigned to M2 (4 milkings $12 \mathrm{~h}$ apart; $\mathrm{n}=$ 21), M1 (2 milkings $24 \mathrm{~h}$ apart; $\mathrm{n}=24)$, MR (4 milkings $12 \mathrm{~h}$ apart; $3 \mathrm{~L} /$ milking; $\mathrm{n}=19)$, or MD (2 milkings $12 \mathrm{~h}$ apart starting at $24 \mathrm{~h}$ after enrollment; $\mathrm{n}=19)$. The Poisson regression model included the main effects of milking strategy $(P=0.09)$, low $\mathrm{Ca}$ at enrollment $(P$ $=0.004)$, breed $(P=0.41)$, parity $(P=0.009)$, and time $(P=0.43)$.
$\mathrm{MD}$ cows $(1.99 \pm 0.07 \mathrm{mmol} / \mathrm{L} ; P=0.18)$. Additional effects included in the model were breed $(P=0.76)$, parity $(P=0.24)$, plasma $\mathrm{P}$ at enrollment $(P=0.003)$, and time $(P=0.30)$. No significant treatment by time effects were observed $(P=0.75)$. At 3 DIM we found a tendency for a milking strategy effect on plasma $\mathrm{P}$ concentration $(P=0.06)$. Compared with M2 cows (2.04 $\pm 0.10 \mathrm{mmol} / \mathrm{L})$, plasma $\mathrm{P}$ concentrations at $3 \mathrm{DIM}$ were higher for M1 $(2.38 \pm 0.09 \mathrm{mmol} / \mathrm{L} ; P=0.05)$ and similar for $\mathrm{MR}(2.33 \pm 0.09 \mathrm{mmol} / \mathrm{L} ; P=0.11)$ and MD cows $(2.16 \pm 0.10 \mathrm{mmol} / \mathrm{L} ; P=0.77)$ while accounting for the effects of breed $(P=0.87)$, parity $(P<0.001)$, and plasma $\mathrm{P}$ at enrollment $(P=0.01)$.

Magnesium. Overall, milking strategy was not associated with plasma $\mathrm{Mg}$ concentration within $48 \mathrm{~h}$ after enrollment (M2: $1.17 \pm 0.03 \mathrm{mmol} / \mathrm{L} ; \mathrm{M} 1: 1.10$ $\pm 0.03 \mathrm{mmol} / \mathrm{L}$; MR: $1.15 \pm 0.03 \mathrm{mmol} / \mathrm{L} ; \mathrm{MD}: 1.14$ $\pm 0.03 \mathrm{mmol} / \mathrm{L} ; P=0.22$; Figure 3$)$. Additional effects included in the model were breed $(P=0.12)$, parity $(P$ $=0.04)$, plasma $\mathrm{Mg}$ at enrollment $(P<0.001)$, interval from calving to enrollment $(P=0.04)$, and time $(P$ $=0.03)$. No significant treatment by time effects were observed $(P=0.30)$. Similarly, at 3 DIM, plasma Mg concentration was not associated with milking strategy (M2: $0.91 \pm 0.04 \mathrm{mmol} / \mathrm{L} ; \mathrm{M} 1: 0.82 \pm 0.04 \mathrm{mmol} / \mathrm{L}$; MR: $0.91 \pm 0.04 \mathrm{mmol} / \mathrm{L}$; MD: $0.89 \pm 0.04 \mathrm{mmol} / \mathrm{L} ; P$ $=0.27)$, accounting for the effects of breed $(P=0.82)$ and parity $(P=0.69)$.

\section{Blood BHB and Hyperketonemia}

No statistically significant milking strategy effects were observed on blood BHB concentration at 3 and 11 DIM (M2: $1.21 \pm 0.12 \mathrm{mmol} / \mathrm{L}$ per day; M1: 1.13 
$\pm 0.12 \mathrm{mmol} / \mathrm{L}$ per day; MR: $1.13 \pm 0.12 \mathrm{mmol} / \mathrm{L}$ per day; MD: $1.03 \pm 0.13 \mathrm{mmol} / \mathrm{L}$ per day; $P=0.85)$. Additional effects included in the model were breed $(P$ $=0.08)$, parity $(P=0.02)$, and time $(P=0.09)$. Prevalence of hyperketonemia (blood $\mathrm{BHB} \geq 1.2 \mathrm{mmol} / \mathrm{L}$ ) at 3 or 11 DIM was $41.8,40.7,18.0$, and $20.7 \%$ for M2, M1, MR, and MD cows, respectively. Two cows had 1 blood BHB observation $>3.0 \mathrm{mmol} / \mathrm{L}(\mathrm{M} 2: \mathrm{n}=1$; MR: $\mathrm{n}=1)$.

\section{Colostrum and Transition Milk Yield and Composition}

Yield. As expected, significant effects of milking strategy and milking strategy by time were observed for colostrum and transition milk yield $(P<0.001$ for both; Figure 5). Compared with M2 cows (0-24 h after enrollment: $11.3 \pm 0.8 \mathrm{~kg} ;>24-48$ h after enrollment: $16.3 \pm 1.4 \mathrm{~kg}$ ) lower colostrum and transition milk yields were observed for M1 cows at 0 to $24 \mathrm{~h}$ after enrollment $(4.7 \pm 0.7 \mathrm{~kg} ; P<0.001)$; MR cows at 0 to $24(4.9 \pm 0.8 \mathrm{~kg} ; P<0.001)$ and $>24$ to $48 \mathrm{~h}$ after enrollment $(5.7 \pm 1.4 \mathrm{~kg} ; P<0.001)$; and MD cows at 0 to $24 \mathrm{~h}$ after enrollment $(0.0 \pm 0.0 \mathrm{~kg} ; P<0.001)$. In contrast, at $>24$ to $48 \mathrm{~h}$ after enrollment, transition milk yield was higher for MD compared with M2 cows $(21.7 \pm 1.4 \mathrm{~kg} ; P=0.02)$. At $>24$ to $48 \mathrm{~h}$ after enrollment, transition milk yield was not statistically different for M2 and M1 cows $(13.0 \pm 1.3 \mathrm{~kg} ; P=$ $0.20)$. Additional effects included in the model were hours post-enrollment $(P<0.001)$, breed $(P=0.78)$, and parity $(P=0.60)$.
Similarly, milking strategy was associated with the total amount of colostrum and transition milk harvested within $48 \mathrm{~h}$ after enrollment $(P<0.001)$. The total amount of colostrum and transition milk harvested was higher for M2 cows $(30.7 \pm 1.5 \mathrm{~kg})$ compared with M1 $(18.2 \pm 1.5 \mathrm{~kg} ; P<0.001), \mathrm{MR}(11.7 \pm 1.5 \mathrm{~kg} ; P<$ $0.001)$, and MD cows $(23.1 \pm 1.6 \mathrm{~kg} ; P=0.003)$, accounting for the effects of breed $(P=0.27)$ and parity $(P=0.31)$.

Calcium Yield. As expected, effects of milking strategy and milking strategy by time were observed for the total amount of Ca harvested in colostrum and transition milk $(P<0.001$ for both; Figure 5). Compared with M2 cows (0-24 h after enrollment: $24.6 \pm$ $1.6 \mathrm{~g} ;>24$ to $48 \mathrm{~h}$ after enrollment: $28.7 \pm 2.4 \mathrm{~g}$ ), total Ca harvested was lower for M1 cows at 0 to $24 \mathrm{~h}$ after enrollment $(12.0 \pm 1.5 \mathrm{~g} ; P<0.001)$, MR cows at 0 to $24(10.7 \pm 1.6 \mathrm{~g} ; P<0.001)$ and $>24$ to $48 \mathrm{~h}$ after enrollment $(10.3 \pm 2.4 \mathrm{~g} ; P<0.001)$, and $\mathrm{MD}$ cows at 0 to $24 \mathrm{~h}$ after enrollment $(0.0 \pm 0.0 \mathrm{~g} ; P<$ 0.001). In contrast, at $>24$ to $48 \mathrm{~h}$ after enrollment, transition milk yield was higher for MD compared with M2 cows $(38.9 \pm 2.4 \mathrm{~g} ; P=0.01)$. At $>24$ to $48 \mathrm{~h}$ after enrollment, transition milk yield was not statistically different for M2 and M1 cows $(25.1 \pm 2.3 \mathrm{~g} ; P=0.54)$. Additional effects included in the model were hours post-enrollment $(P<0.001)$, breed $(P=0.93)$, and parity $(P=0.12)$.

Likewise, postpartum milking strategy was associated with the total amount of $\mathrm{Ca}$ harvested in colostrum and transition milk within $48 \mathrm{~h}$ after enrollment $(P<$ 0.001). The total amount of Ca harvested in colostrum

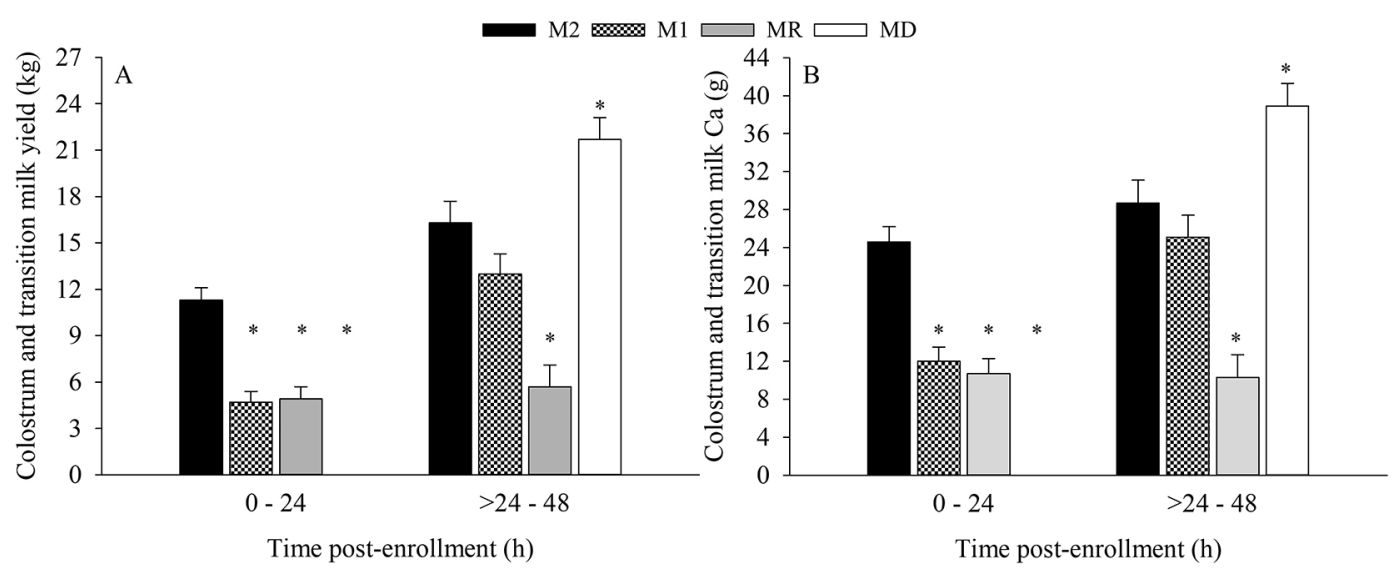

Figure 5. Colostrum and transition milk (A) and calcium (Ca; B) harvested from 0 to $24 \mathrm{~h}$ and from $>24 \mathrm{~h}$ to $48 \mathrm{~h}$ after enrollment from multiparous Jersey and Jersey $\times$ Holstein crossbreed cows assigned to M2 (4 milkings $12 \mathrm{~h}$ apart; $\mathrm{n}=21)$, M1 (2 milkings $24 \mathrm{~h}$ apart; $\mathrm{n}=24)$, MR (4 milkings $12 \mathrm{~h}$ apart; $3 \mathrm{~L} /$ milking; $\mathrm{n}=19)$, or MD (2 milkings $12 \mathrm{~h}$ apart starting at $24 \mathrm{~h}$ after enrollment; $\mathrm{n}=19)$. *Differences compared with M2 cows at $P<0.05$. Colostrum and transition milk model included the effects of milking strategy $(P<0.001)$, hours post-enrollment $(P<0.001)$, milking strategy by hours post-enrollment $(P<0.001)$, breed $(P=0.78)$, and parity $(P=0.60)$; Ca model included the effects of milking strategy $(P<0.001)$, hours post-enrollment $(P<0.001)$, milking strategy by hours post-enrollment $(P<0.001)$, breed $(P=0.93)$, and parity $(P=0.12)$. 
Table 3. Colostrum and transition milk IgG concentration $(\mathrm{g} / \mathrm{L} ; \mathrm{LSM} \pm \mathrm{SE}$ ) by postpartum milking and postpartum milking strategy for multiparous Jersey and Jersey $\times$ Holstein crossbreed cows

\begin{tabular}{|c|c|c|c|c|c|c|}
\hline \multirow{2}{*}{$\begin{array}{l}\text { Postpartum } \\
\text { milking }\end{array}$} & \multicolumn{4}{|c|}{ Milking strategy $^{1}$} & \multirow[b]{2}{*}{ Breed } & \multirow[b]{2}{*}{ Parity } \\
\hline & M2 & M1 & MR & $\mathrm{MD}$ & & \\
\hline 1 & $78.4 \pm 5.1^{\mathrm{a}}$ & $93.5 \pm 5.3^{\mathrm{a}}$ & $78.4 \pm 5.1^{\mathrm{a}}$ & $43.5 \pm 5.6^{\mathrm{b}}$ & 0.34 & $<0.001$ \\
\hline 2 & $43.7 \pm 4.0^{\mathrm{a}}$ & $26.2 \pm 3.9^{\mathrm{b}}$ & $67.1 \pm 4.0^{\mathrm{b}}$ & $17.7 \pm 4.1^{\mathrm{b}}$ & 0.97 & $<0.001$ \\
\hline 3 & $17.6 \pm 5.1^{\mathrm{a}}$ & - & $40.4 \pm 5.1^{\mathrm{b}}$ & - & 0.20 & 0.24 \\
\hline 4 & $9.8 \pm 3.0^{\mathrm{a}}$ & - & $18.6 \pm 3.2^{\mathrm{b}}$ & - & 0.30 & 0.09 \\
\hline
\end{tabular}

${ }_{\mathrm{a}, \mathrm{b}}$ Within row, values with different superscripts indicate differences compared with $\mathrm{M} 2$ at $P<0.05$.

${ }^{1}$ Within $48 \mathrm{~h}$ after enrollment for cows milked 4 times $12 \mathrm{~h}$ apart $(\mathrm{M} 2 ; \mathrm{n}=21)$, twice $24 \mathrm{~h}$ apart $(\mathrm{M} 1 ; \mathrm{n}=24), 4$ times $12 \mathrm{~h}$ apart ( $3 \mathrm{~L} /$ milking; $\mathrm{MR} ; \mathrm{n}=19)$, or twice $12 \mathrm{~h}$ apart starting at $24 \mathrm{~h}$ after enrollment $(\mathrm{MD} ; \mathrm{n}=19)$.

and transition milk was higher for M2 cows $(53.8 \pm 3.2$ g) compared with $\mathrm{MD}(39.1 \pm 3.3 \mathrm{~g} ; P<0.001)$, MR $(21.4 \pm 3.2 \mathrm{~g} ; P<0.001)$, and M1 cows $(36.7 \pm 3.0 \mathrm{~g} ; P$ $=0.005)$, accounting for the effects of breed $(P=0.40)$ and parity $(P=0.06)$.

IgG Concentration. Effects of milking strategy on colostrum and transition milk IgG concentration by postpartum milking number, and additional effects in the models, are described in Table 3. Compared with M2 cows, IgG concentration was, at first postpartum milking, lower for MD $(P<0.001)$ and similar for M1 $(P=0.11)$ and MR cows $(P=0.13)$; at second postpartum milking, higher for MR $(P<0.001)$ and lower for M1 $(P=0.007)$ and MD cows $(P<0.001)$; and at third and fourth postpartum milking, higher for MR cows $(P$ $=0.003$ and 0.04 , respectively).

The proportion of cows producing good colostrum (>50 g IgG/L) and the average kilograms of good colostrum per cow on the milking strategy (mean $\pm \mathrm{SD}$ ) were, at first postpartum milking, $80.0 \%$ and $4.4 \pm 2.9$ $\mathrm{kg}$ for $\mathrm{M} 2,86.4 \%$ and $5.5 \pm 4.0 \mathrm{~kg}$ for $\mathrm{M} 1,79.0 \%$ and $2.6 \pm 3.0 \mathrm{~kg}$ for $\mathrm{MR}$, and $21.1 \%$ and $2.1 \pm 1.4 \mathrm{~kg}$ for MD cows; and at second postpartum milking, $40.0 \%$ and $2.3 \pm 3.3 \mathrm{~kg}$ for M2, $4.6 \%$ and $0.3 \pm 1.2 \mathrm{~kg}$ for M1, $68.4 \%$ and $1.9 \pm 1.4 \mathrm{~kg}$ for $\mathrm{MR}$, and $0.0 \%$ and $0.0 \pm 0.0$ $\mathrm{kg}$ for MD cows. At third and fourth postpartum milkings, the proportion of cows producing good colostrum and the average kilograms of good colostrum per cow on the milking strategy were, for M2 cows, $5.3 \%$ and $0.2 \pm 0.1 \mathrm{~kg}$ and $5.0 \%$ and $0.5 \pm 2.2 \mathrm{~kg}$, and, for MR cows, $31.6 \%$ and $0.9 \pm 1.4 \mathrm{~kg}$ and $5.0 \%$ and $0.2 \pm 0.7$ $\mathrm{kg}$, respectively.

Somatic Cell Count. No statistically significant association was observed between postpartum milking strategy and average SCC within $48 \mathrm{~h}$ after enrollment $(P=0.30)$. On average SCC was $888.6 \pm 186.0$ cells/ $\mu \mathrm{L}$ for $\mathrm{M} 2,1,305.1 \pm 176.9$ cells $/ \mu \mathrm{L}$ for $\mathrm{M} 1,1,207.7 \pm$ 185.9 cells $/ \mu \mathrm{L}$ for $\mathrm{MR}$, and $888.6 \pm 186.0$ cells $/ \mu \mathrm{L}$ for MD cows, accounting for the effects of breed $(P=0.53)$ and parity $(P=0.14)$.

\section{Milk Yield and Composition at First Monthly Test}

Milk Yield. No statistically significant milking strategy effect was observed on milk yield at first monthly test $(P=0.82)$. Observed milk yields were $32.2 \pm 1.3$ $\mathrm{kg}$ for M2, $33.4 \pm 1.3 \mathrm{~kg}$ for M1, $31.8 \pm 1.4 \mathrm{~kg}$ for $\mathrm{MR}$, and $32.6 \pm 1.4 \mathrm{~kg}$ for MD cows. Additional effects included in the model were breed $(P=0.001)$ and parity $(P=0.31)$.

Energy-Corrected Milk Yield. No statistically significant differences were observed on ECM at first monthly test associated with the milking strategy $(P=$ $0.75)$. Observed ECM yields were $35.7 \pm 1.4 \mathrm{~kg}$ for M2, $37.3 \pm 1.4 \mathrm{~kg}$ for M1, $35.3 \pm 1.4 \mathrm{~kg}$ for MR, and $36.2 \pm$ $1.5 \mathrm{~kg}$ for MD cows. Additional effects included in the model were breed $(P=0.13)$ and parity $(P<0.001)$.

Somatic Cell Count. No statistically significant milking strategy effect was observed on SCC at first monthly test $(P=0.69)$. Observed SCC were $317.5 \pm$ 148.3 cells $/ \mu \mathrm{L}$ for $\mathrm{M} 2,339.4 \pm 145.2$ cells $/ \mu \mathrm{L}$ for M1, $475.1 \pm 148.3$ cells $/ \mu \mathrm{L}$ for MR, and $234.8 \pm 159.7$ cells $/$ $\mu \mathrm{L}$ for MD cows, accounting for the effects of breed $(P=0.13)$ and parity $(P<0.001)$. Four cows were diagnosed with clinical mastitis within 11 DIM (M2: $\mathrm{n}$ $=1 ; \mathrm{M} 1: \mathrm{n}=1 ; \mathrm{MR}: \mathrm{n}=2$ ).

\section{DISCUSSION}

Peripartum mineral balance has attracted researchers' attention since the first observation of low blood Ca concentration in cows suffering from milk fever in 1925 (Hibbs, 1950). The association between blood Ca concentration and lactation onset is supported by research comparing mastectomized cows against cows with intact udder (Niedermeier et al., 1949); mastectomy prevented hypocalcemia following parturition in multiparous Jersey cows fed a positive DCAD prepartum diet (Goff et al., 2002). Furthermore, a study by Littledike (1976) showed a relationship between milk secretion and hypocalcemia, alternating periods of 
milking and no milking after parturition. Thus, limiting the Ca output in colostrum and transition milk through modified postpartum milking strategies can help to modulate blood $\mathrm{Ca}$ concentration in the postpartum period. Nevertheless, common concerns associated with limiting the amount of colostrum, transition milk, and milk harvested include colostrum supply, udder health, and future milk yield.

Earlier studies evaluated the implications of postpartum milking strategies aimed at reducing colostrum and transition milk outputs; however, only a few studies have evaluated its association with blood mineral concentrations. The milking strategies evaluated were once-a-day milking for the first week postpartum (serum $\mathrm{Ca}$ and P; Loiselle et al., 2009), restricted milking at first (3 $\mathrm{L})$ and second $(4 \mathrm{~L})$ postpartum milkings (serum Ca, P, and Mg; Salgado-Hernández et al., 2014), and restricted milking (1/3 of expected yield) during the first 5 d postpartum (serum P; Carbonneau et al., 2012). In agreement with our findings, Loiselle et al. (2009) did not observe effects on serum $\mathrm{Ca}$ and $\mathrm{P}$ during the first $2 \mathrm{~d}$ of once-a-day milking but found higher serum Ca concentration at 4 DIM and P at 4 and 5 DIM in cows milked once daily, compared with cows milked twice daily, and no differences after the treatment period. Carbonneau et al. (2012) observed a higher serum P concentration in restricted-milking cows compared with cows milked twice a day, but similar $\mathrm{P}$ concentrations were observed $9 \mathrm{~d}$ after treatment completion. In contrast, Salgado-Hernández et al. (2014) did not observe an effect of restricted milking on serum $\mathrm{Ca}, \mathrm{P}$, and $\mathrm{Mg}$ concentrations. That study limited the restricted milking strategy to the first 2 postpartum milkings, but at second milking the amount of colostrum harvested was not statistically different for restricted milking and control cows, likely limiting the magnitude of the effects associated with the milking strategy. In our study, the restricted milking strategy was imposed during the first $48 \mathrm{~h}$ postpartum and led to significantly lower amounts of colostrum and transition milk harvested within 48 $\mathrm{h}$ after enrollment in MR compared with M2 cows. Decreased milk secretion rate, mammary blood flow, and nutrient uptake in MR and MD cows may explain the higher plasma Ca concentration in these cows compared with M2 cows (Elliott et al., 1960; Delamaire and Guinard-Flament, 2006; Penry et al., 2017). Calcium is the most abundant mineral in colostrum and transition milk, followed by $\mathrm{P}$ (Cerbulis and Farrell, 1976; Kehoe et al., 2007; Tsioulpas et al., 2007). Therefore, it is not surprising that reducing the amount of colostrum and transition milk harvested has a stronger effect on these minerals, compared with $\mathrm{Mg}$, which is present in smaller quantities. A longer treatment period might be necessary to detect milking strategy effects on plasma $\mathrm{P}$ and $\mathrm{Mg}$ concentrations. Despite the different milking intervals associated with the evaluated milking strategies, we did not observe treatment effects conditional to time in plasma mineral concentrations; the treatment by time interactions were excluded from the final models at $P=0.78$ (plasma Ca), $P=0.75$ (plasma $\mathrm{P}$ ), and $P=0.30$ (plasma $\mathrm{Mg}$ ), respectively. It is noteworthy to highlight that study cows were fed a negative DCAD diet prepartum $(-16.20 \mathrm{mEq} / 100 \mathrm{~g}$ of DM) as a prophylactic strategy for hypocalcemia, and, thus, it may have influenced the observed effects on plasma mineral concentrations. Nevertheless, we did not evaluate the effectiveness of the DCAD program and cannot be certain that enrolled cows were successfully acidified during the close-up period. Furthermore, it is uncertain whether milking strategy effects would have been greater if cows were fed a positive DCAD diet. A positive DCAD diet (98 mEq/ $\mathrm{kg}$ of DM) was fed to prepartum cows in the study by Salgado-Hernández et al. (2014), but that information is not provided in the studies by Loiselle et al. (2009) and Carbonneau et al. (2012). Thus, further research should evaluate the strategies proposed herein independently from other strategies for hypocalcemia prevention and compared with a combination of strategies.

Blood BHB concentration was not associated with milking strategy in our study; however, important numerical differences were observed in the proportion of cows with subclinical ketosis at 3 or 11 DIM. The incidence of subclinical ketosis was numerically double for M2 and M1 cows (42 and 41\%, respectively) compared with MR and MD cows (18 and 21\%, respectively). Research on postpartum milking alternatives has been based on the premise that reducing the amount of milk harvested postpartum would decrease the nutrient demands and lower the negative energy balance (Lacasse et al., 2018). Once-a-day milking for 1 to 6 wk postpartum, or restricted milking and nursing combined with once-a-day milking during the first $5 \mathrm{~d}$ postpartum, improved blood markers of energy balance (increased glucose along with decreased NEFA and BHB) compared with twice-a-day milking (McNamara et al., 2008; Loiselle et al., 2009; Carbonneau et al., 2012; Phyn et al., 2014). In our study, the milking strategies were imposed only for the first $2 \mathrm{~d}$ postpartum, perhaps limiting the size of the milking strategy effect compared with studies where the strategies were implemented for at least $5 \mathrm{~d}$ postpartum.

Milking strategies that aim to minimize colostrum and transition milk yield may compromise the supply of good-quality colostrum. In our study, first-milking colostrum IgG concentrations were similar for M2, M1, and MR cows; however, as expected, after delaying milking, IgG concentration at first milking was lower 
for MD cows (Moore et al., 2005). Based on first milking, M1 and M2 milking strategies will provide enough good-quality colostrum. However, to achieve an adequate supply with MR ( $\geq 3 \mathrm{~L}$ of colostrum with $\operatorname{IgG}$ $>50 \mathrm{mg} / \mathrm{dL}$ per cow), colostrum should be harvested at first and second milking. The remaining colostrum from the initial incomplete udder emptying, or the decreased milk secretion rate, may explain the higher subsequent transition milk IgG concentrations observed in MR cows (Penry et al., 2017). As expected, not milking the cows for $24 \mathrm{~h}$ following enrollment (MD) prevented the harvest of good-quality colostrum, making the aforementioned strategy unsuitable for dairies that rely on own colostrum supply for newborn calves. Last, it should be noted that we followed the study farm milking schedule with a calving-to-first milking interval of $9 \mathrm{~h} 36 \mathrm{~min} \pm 3 \mathrm{~h} 48 \mathrm{~min}$ for M2, M1, and MR. Although this extended interval reflects industry practices (Kehoe et al., 2007; Silva-del-Río et al., 2017), it disagrees with recommendations of early postpartum milking for good-quality colostrum harvesting (Moore et al., 2005; Godden, 2008). Further research is needed to identify the modified postpartum milking strategy that would allow for good-quality colostrum harvesting and significantly improve blood Ca balance during early postpartum.

Multiple factors may influence colostrum yield and composition, and therefore these must be considered before extrapolating the results from our study. For instance, colostrum yield at first postpartum milking is potentially influenced by parity, dry period length, calf sex, twinning, month of calving, and previous lactation length in Jersey cows (Gavin et al., 2018). In our study, colostrum was not harvested from 4 cows $(4.8 \%$; M2: $\mathrm{n}$ $=1 ; \mathrm{M} 1: \mathrm{n}=1 ; \mathrm{MR}: \mathrm{n}=2)$, and $<1 \mathrm{~kg}$ was harvested from 4 cows (M2: $\mathrm{n}=1 ; \mathrm{M} 1: \mathrm{n}=1 ; \mathrm{MR}: \mathrm{n}=2$ ) at their respective first postpartum milking, whereas up to $13 \mathrm{~kg}$ were harvested from a cow assigned to M2. In agreement, Gavin et al. (2018) reported that no colostrum was harvested from $6 \%$ of the multiparous Jersey cows in their study, and a range of 0 to $26.5 \mathrm{~kg}$ of colostrum was found. The present study was conducted with Jersey and Jersey $\times$ Holstein crossbreed cows. Overall, Jerseys have lower yields and higher milk Ca and $\mathrm{P}$ concentrations than Holstein and other breeds (Cerbulis and Farrell, 1976). However, colostrum Ca concentrations in this study $(54.86$ and $50.14 \mathrm{mmol} / \mathrm{L}$ for multiparous Jersey and Jersey $\times$ Holstein crossbreed cows, respectively) are similar to previous observations in Holstein-Friesian $(54.2 \mathrm{mmol} / \mathrm{L}$; Tsioulpas et al., 2007) and Holstein cows $(52.15 \mathrm{mmol} / \mathrm{L}$; Kume and Tanabe, 1993). Thus, given the higher yields associated with Holstein cows, we speculate that a larger effect on plasma $\mathrm{Ca}$ concentration could be achieved with the postpartum milking strategies described in the present study, if implemented in Holstein cows. Moreover, previous research reported a smaller influence on milk yield and composition of once-a-day milking in Jersey compared with Holstein cows (Clark et al., 2006). Therefore, it is plausible that the evaluated milking strategies would produce a different response on milk yield and composition in Holstein cows.

Long-term implementation of incomplete milking has been shown to reduce milk yield, likely due to a decrease in mammary gland secretory activity (Stelwagen et al., 2013). In our study, reducing milking frequency and restricting milk harvest for $48 \mathrm{~h}$ postpartum does not seem to have long-lasting changes in the mammary gland secretory tissue. Milk and ECM yields and SCC at first monthly test were not affected by milking strategy in our study. Similarly, Carbonneau et al. (2012) and Krug et al. (2018c) did not observe a residual effect on milk production after implementing restricted milking during the first $5 \mathrm{~d}$ postpartum. In contrast, once-a-day milking for 1,3 , or 6 wk postpartum had a negative carryover effect on milk yield, with cows milked once a day producing 6 to $8 \%$ less than cows milked twice a day, up to at least $10 \mathrm{wk}$ after the reduced milking frequency period (Loiselle et al., 2009; Phyn et al., 2014). The effects on milk composition vary between studies, likely because milk composition is also modified by some of the implemented strategies (Schlamberger et al., 2010). No effect on ECM yield was observed when once-a-day milking was limited to the first week postpartum (Loiselle et al., 2009), but once-a-day milking for 3 wk postpartum had detrimental effects that carried over to 8 mo in lactation (Phyn et al., 2014). In agreement with our observation, SCC was not affected by restricted or once-a-day milking for the first week postpartum (Loiselle et al., 2009; Carbonneau et al., 2012).

The works by Krug et al. (2018a,b,c) and Morin et al. (2018), based on a large study in which producers from 13 dairy farms were instructed to implement a restricted milking strategy for $5 \mathrm{~d}$ postpartum (maximum of 10,12 , and $14 \mathrm{~L} / \mathrm{d}$ of milk at $1-3,4$, and 5 DIM, respectively; $\mathrm{n}>800$ multiparous Holstein lactations), suggest that restricted milking for $5 \mathrm{~d}$ postpartum does not have effects on future milk yield and composition, culling hazard, clinical mastitis, or reproductive tract health, but reduces ketonemia and hyperketonemia in early postpartum, and may have positive effects on reproduction (increased pregnancy hazard on secondparity cows with a voluntary waiting period $<55 \mathrm{~d}$ ). Nevertheless, considering yields from conventionally milked cows (6 L at 1 DIM), the aforementioned strategy would most likely have limited the amount of milk harvested only from 2 to 5 DIM. Larger studies 
designed to detect effects on production, reproduction, and health are needed to investigate the implications and assess the profitability of the once-a-day (M1) and restricted (MR) postpartum milking strategies proposed in the present study.

Sample size for this study was calculated based on the assumption that plasma Ca concentration would remain roughly constant after initial udder fill if MD cows were not milked. However, because this assumption was made in absence of specific data, this may have underpowered our study and potentially hindered our ability to detect larger effects on plasma Ca concentration. Furthermore, inflammation, disease, and DM intake around parturition interfere with blood $\mathrm{Ca}$ dynamics postpartum (Venjakob et al., 2019; Horst et al., 2021; Seely et al., 2021). Thus, it is plausible that, although enrolled cows were defined as healthy at the time of enrollment [not displaying clinical signs of disease or sick cow behavior based on the subjective interpretation of the first author (DVM)], concomitant conditions such as those described in the aforementioned research may have influenced the results presented herein. Despite these limitations, the present study provides a base for further research studies looking to evaluate alternative management strategies to improve cows' health and welfare during the early postpartum period and subsequent production and reproduction.

\section{CONCLUSIONS}

Our results suggest that postpartum plasma Ca concentration may be influenced by postpartum milking strategies that reduce the total amount of colostrum and transition milk harvested during the first $2 \mathrm{~d}$ postpartum. Colostrum quantity and quality are affected by postpartum milking strategy; once-a-day and restricted milking ensure enough good-quality colostrum to meet industry standards, but delayed milking prevents good-quality colostrum harvesting. However, restricted milking would require harvesting colostrum from first and second postpartum milkings. Limiting the amount of colostrum and transition milk harvested during the first $2 \mathrm{~d}$ postpartum does not seem to have detrimental effects on udder health, milk yield, and ECM yield. Thus, postpartum milking strategies warrant further investigation as alternative management strategies to modulate postpartum mineral balances. Additional studies, with adequate sample size, should be conducted to evaluate the effects of the proposed postpartum milking strategies, which aim at reducing the amount of colostrum and transition milk harvested postpartum, on production, reproduction, and health.

\section{ACKNOWLEDGMENTS}

Funding for this study was provided by the Center for Food Animal Health (no. CA-V-PHR-4099-H; Davis, CA). We thank PortaCheck (Moorestown, NJ) and DeLaval International AB (Tumba, Sweden) for providing part of the supplies used in this study. We gratefully acknowledge the support of Maira Cuffia, Joaquin Chiozza-Logroño, and Eber Rojas (Veterinary Medicine Teaching and Research Center, Tulare, CA), and Fran Zarauza (DairyExperts, Tulare, CA) in data collection. We further thank the participating dairy for allowing us to use their facilities, cows, and records. The authors have not stated any conflicts of interest.

\section{REFERENCES}

Brady, M. D. 2013. A survey of calcium status of dairy cattle residing in California's Central Valley. MS thesis. Jordan College of Agricultural Sciences and Technology, California State University, Fresno.

Caixeta, L. S., P. A. Ospina, M. B. Capel, and D. V. Nydam. 2017. Association between subclinical hypocalcemia in the first 3 days of lactation and reproductive performance of dairy cows. Theriogenology 94:1-7. https://doi.org/10.1016/j.theriogenology.2017.01 .039 .

Carbonneau, E., A. M. de Passillé, J. Rushen, B. G. Talbot, and P. Lacasse. 2012. The effect of incomplete milking or nursing on milk production, blood metabolites, and immune functions of dairy cows. J. Dairy Sci. 95:6503-6512. https://doi.org/10.3168/jds.2012 $-5643$.

Cerbulis, J., and H. M. Farrell Jr.. 1976. Composition of the milks of dairy cattle. II. Ash, calcium, magnesium, and phosphorus. J. Dairy Sci. 59:589-593. https://doi.org/10.3168/jds.S0022 $-0302(76) 84245-2$.

Clark, D. A., C. V. C. Phyn, M. J. Tong, S. J. Collis, and D. E. Dalley. 2006. A systems comparison of once- versus twice-daily milking of pastured dairy cows. J. Dairy Sci. 89:1854-1862. https://doi.org/ 10.3168/jds.S0022-0302(06)72254-8.

Delamaire, E., and J. Guinard-Flament. 2006. Increasing milking intervals decreases the mammary blood flow and mammary uptake of nutrients in dairy cows. J. Dairy Sci. 89:3439-3446. https://do .org/10.3168/jds.S0022-0302(06)72381-5.

Elliott, G. M., F. H. Dodd, and P. J. Brumby. 1960. Variations in the rate of milk secretion in milking intervals of 2-24 hours. J. Dairy Res. 27:293-308. https://doi.org/10.1017/S0022029900010360.

Ferguson, J. D., D. T. Galligan, and N. Thomsen. 1994. Principal descriptors of body condition score in Holstein cows. J. Dairy Sci. 77:2695-2703. https://doi.org/10.3168/jds.S0022-0302(94)77212 $-\mathrm{X}$.

Gavin, K., H. Neibergs, A. Hoffman, J. N. Kiser, M. A. Cornmesser, S. A. Haredasht, B. Martínez-López, J. R. Wenz, and D. A. Moore. 2018. Low colostrum yield in Jersey cattle and potential risk factors. J. Dairy Sci. 101:6388-6398. https://doi.org/10.3168/ jds.2017-14308.

Godden, S. 2008. Colostrum management for dairy calves. Vet. Clin. North Am. Food Anim. Pract. 24:19-39. https://doi.org/10.1016/ j.cvfa.2007.10.005.

Goff, J. P. 2004. Macromineral disorders of the transition cow. Vet. Clin. North Am. Food Anim. Pract. 20:471-494. https://doi.org/ 10.1016/j.cvfa.2004.06.003.

Goff, J. P., K. Kimura, and R. L. Horst. 2002. Effect of mastectomy on milk fever, energy, and vitamins $\mathrm{A}, \mathrm{E}$, and $\beta$-carotene status at parturition. J. Dairy Sci. 85:1427-1436. https://doi.org/10.3168/ jds.S0022-0302(02)74210-0. 
Hibbs, J. W. 1950. Milk fever (parturient paresis) in dairy cows-A review. J. Dairy Sci. 33:758-789. https://doi.org/10.3168/jds.S0022 -0302(50)91966-7.

Horst, E. A., S. K. Kvidera, and L. H. Baumgard. 2021. Invited review: The influence of immune activation on transition cow health and performance $\mathrm{A}$ critical evaluation of traditional dogmas. J. Dairy Sci. 104:8380-8410. https://doi.org/10.3168/jds.2021-20330.

Kehoe, S. I., B. M. Jayarao, and A. J. Heinrichs. 2007. A survey of bovine colostrum composition and colostrum management practices on Pennsylvania dairy farms. J. Dairy Sci. 90:4108-4116. https:// doi.org/10.3168/jds.2007-0040.

Kimura, K., T. A. Reinhardt, and J. P. Goff. 2006. Parturition and hypocalcemia blunts calcium signals in immune cells of dairy cattle. J. Dairy Sci. 89:2588-2595. https://doi.org/10.3168/jds.S0022 -0302(06)72335-9.

Krug, C., P. A. Morin, P. Lacasse, J. P. Roy, J. Dubuc, and S. Dufour. 2018a. A randomized controlled trial on the effect of incomplete milking during the first 5 days in milk on reproductive performance of dairy cows. J. Dairy Sci. 101:11330-11341. https://doi .org/10.3168/jds.2018-14909.

Krug, C., P. A. Morin, P. Lacasse, J. P. Roy, J. Dubuc, and S. Dufour. 2018b. Effect of incomplete milking during the first 5 days in milk on udder and reproductive tract health: Results from a randomized controlled trial. J. Dairy Sci. 101:9275-9286. https://doi.org/ 10.3168/jds.2018-14713.

Krug, C., P. A. Morin, P. Lacasse, D. E. Santschi, J. P. Roy, J. Dubuc, and S. Dufour. 2018c. A randomized controlled trial on the effect of incomplete milking during the first 5 days in milk on culling hazard and on milk production and composition of dairy cows. J. Dairy Sci. 101:4367-4377. https://doi.org/10.3168/jds.2017-14021.

Kume, S., and S. Tanabe. 1993. Effect of parity on colostral mineral concentrations of Holstein cows and value of colostrum as a mineral source for newborn calves. J. Dairy Sci. 76:1654-1660. https:/ /doi.org/10.3168/jds.S0022-0302(93)77499-8.

Lacasse, P., N. Vanacker, S. Ollier, and C. Ster. 2018. Innovative dairy cow management to improve resistance to metabolic and infectious diseases during the transition period. Res. Vet. Sci. 116:40-46. https://doi.org/10.1016/j.rvsc.2017.06.020.

Leno, B. M., R. C. Neves, I. M. Louge, M. D. Curler, M. J. Thomas, T. R. Overton, and J. A. A. McArt. 2018. Differential effects of a single dose of oral calcium based on postpartum plasma calcium concentration in Holstein cows. J. Dairy Sci. 101:3285-3302. https: //doi.org/10.3168/jds.2017-13164.

Littledike, E. T. 1976. Relationship of milk secretion to hypocalcemia in the dairy cow. J. Dairy Sci. 59:1947-1953. https://doi.org/10 .3168/jds.S0022-0302(76)84466-9.

Loiselle, M. C., C. Ster, B. G. Talbot, X. Zhao, G. F. Wagner, Y. R. Boisclair, and P. Lacasse. 2009. Impact of postpartum milking frequency on the immune system and the blood metabolite concentration of dairy cows. J. Dairy Sci. 92:1900-1912. https://doi.org/ 10.3168/jds.2008-1399.

Martinez, N., C. A. Risco, F. S. Lima, R. S. Bisinotto, L. F. Greco, E. S. Ribeiro, F. Maunsell, K. Galvão, and J. E. P. Santos. 2012. Evaluation of peripartal calcium status, energetic profile, and neutrophil function in dairy cows at low or high risk of developing uterine disease. J. Dairy Sci. 95:7158-7172. https://doi.org/10 $.3168 /$ jds.2012-5812.

Martinez, N., L. D. P. Sinedino, R. S. Bisinotto, R. Daetz, C. A. Risco, K. N. Galvão, W. W. Thatcher, and J. E. P. Santos. 2016. Effects of oral calcium supplementation on productive and reproductive performance in Holstein cows. J. Dairy Sci. 99:8417-8430. https:/ /doi.org/10.3168/jds.2015-10529.

McArt, J. A. A., and R. C. Neves. 2020. Association of transient, persistent, or delayed subclinical hypocalcemia with early lactation disease, removal, and milk yield in Holstein cows. J. Dairy Sci. 103:690-701. https://doi.org/10.3168/jds.2019-17191.

McNamara, S., J. J. Murphy, F. P. O'Mara, M. Rath, and J. F. Mee. 2008. Effect of milking frequency in early lactation on energy metabolism, milk production and reproductive performance of dairy cows. Livest. Sci. 117:70-78. https://doi.org/10.1016/j.livsci.2007 .11 .013 .
Melton, L. A., M. L. Tracy, and G. Möller. 1990. Screening trace elements and electrolytes in serum by inductively-coupled plasma emission spectrometry. Clin. Chem. 36:247-250. https://doi.org/ 10.1093/clinchem/36.2.247.

Moore, M., J. W. Tyler, M. Chigerwe, M. E. Dawes, and J. R. Middleton. 2005. Effect of delayed colostrum collection on colostral IgG concentration in dairy cows. J. Am. Vet. Med. Assoc. 226:13751377. https://doi.org/10.2460/javma.2005.226.1375.

Morin, P. A., C. Krug, Y. Chorfi, J. Dubuc, P. Lacasse, J. P. Roy, D. E. Santschi, and S. Dufour. 2018. A randomized controlled trial on the effect of incomplete milking during early lactation on ketonemia and body condition loss in Holstein dairy cows. J. Dairy Sci. 101:4513-4526. https://doi.org/10.3168/jds.2017-13151.

Neves, R. C., B. M. Leno, T. Stokol, T. R. Overton, and J. A. A. McArt. 2017. Risk factors associated with postpartum subclinical hypocalcemia in dairy cows. J. Dairy Sci. 100:3796-3804. https:// doi.org/10.3168/jds.2016-11970.

Niedermeier, R. P., V. R. Smith, and C. K. Whitehair. 1949. Parturient paresis. III. A study of various blood constituents at parturition in mastectomized cows. J. Dairy Sci. 32:927-934. https://doi .org/10.3168/jds.S0022-0302(49)92140-2.

Oetzel, G. R. 2013. Oral calcium supplementation in peripartum dairy cows. Vet. Clin. North Am. Food Anim. Pract. 29:447-455. https: //doi.org/10.1016/j.cvfa.2013.03.006.

Oetzel, G. R., and B. E. Miller. 2012. Effect of oral calcium bolus supplementation on early-lactation health and milk yield in commercial dairy herds. J. Dairy Sci. 95:7051-7065. https://doi.org/ $10.3168 /$ jds.2012-5510

Penry, J. F., E. L. Endres, B. de Bruijn, A. Kleinhans, P. M. Crump, D. J. Reinemann, and L. L. Hernandez. 2017. Effect of incomplete milking on milk production rate and composition with 2 daily milkings. J. Dairy Sci. 100:1535-1540. https://doi.org/10.3168/jds .2016-11935.

Phyn, C. V. C., J. K. Kay, A. G. Rius, S. R. Morgan, C. G. Roach, T. M. Grala, and J. R. Roche. 2014. Temporary alterations to postpartum milking frequency affect whole-lactation milk production and the energy status of pasture-grazed dairy cows. J. Dairy Sci. 97:6850-6868. https://doi.org/10.3168/jds.2013-7836.

Ramos-Nieves, J. M., B. J. Thering, M. R. Waldron, P. W. Jardon, and T. R. Overton. 2009. Effects of anion supplementation to lowpotassium prepartum diets on macromineral status and performance of periparturient dairy cows. J. Dairy Sci. 92:5677-5691. https://doi.org/10.3168/jds.2009-2378.

Rodríguez, E. M., A. Arís, and A. Bach. 2017. Associations between subclinical hypocalcemia and postparturient diseases in dairy cows. J. Dairy Sci. 100:7427-7434. https://doi.org/10.3168/jds .2016-12210.

Saborío-Montero, A., B. Vargas-Leitón, J. J. Romero-Zúñiga, and J. M. Sánchez. 2017. Risk factors associated with milk fever occurrence in grazing dairy cattle. J. Dairy Sci. 100:9715-9722. https:/ /doi.org/10.3168/jds.2017-13065.

Sailer, K. J., R. S. Pralle, R. C. Oliveira, S. J. Erb, G. R. Oetzel, and H. M. White. 2018. Technical note: Validation of the BHBCheck blood $\beta$-hydroxybutyrate meter as a diagnostic tool for hyperketonemia in dairy cows. J. Dairy Sci. 101:1524-1529. https://doi.org/ $10.3168 /$ jds.2017-13583.

Salgado-Hernández, E. G., A. Aparicio-Cecilio, F. H. Velásquez-Forero, D. A. Castillo-Mata, and J. Bouda. 2014. Effect of the first and second postpartum partial milking on blood serum calcium concentration in dairy cows. Czech J. Anim. Sci. 59:128-133. https:// doi.org/10.17221/7292-CJAS.

Santos, J. E. P., I. J. Lean, H. Golder, and E. Block. 2019. Meta-analysis of the effects of prepartum dietary cation-anion difference on performance and health of dairy cows. J. Dairy Sci. 102:2134-2154. https://doi.org/10.3168/jds.2018-14628.

Schlamberger, G., S. Wiedemann, E. Viturro, H. H. D. Meyer, and M. Kaske. 2010. Effects of continuous milking during the dry period or once daily milking in the first 4 weeks of lactation on metabolism and productivity of dairy cows. J. Dairy Sci. 93:2471-2485. https://doi.org/10.3168/jds.2009-2823. 
Seely, C. R., B. M. Leno, A. L. Kerwin, T. R. Overton, and J. A. A. McArt. 2021. Association of subclinical hypocalcemia dynamics with dry matter intake, milk yield, and blood minerals during the periparturient period. J. Dairy Sci. 104:4692-4702. https://doi .org/10.3168/jds.2020-19344.

Silva-del-Río, N., D. Rolle, A. García-Muñoz, S. Rodríguez-Jiménez, A. Valldecabres, A. Lago, and P. Pandey. 2017. Colostrum immunoglobulin G concentration of multiparous Jersey cows at first and second milking is associated with parity, colostrum yield, and time of first milking, and can be estimated with Brix refractometry. J. Dairy Sci. 100:5774-5781. https://doi.org/10.3168/jds.2016-12394.

Stelwagen, K., C. V. C. Phyn, S. R. Davis, J. Guinard-Flament, D. Pomiès, J. R. Roche, and J. K. Kay. 2013. Invited review: Reduced milking frequency: Milk production and management implications. J. Dairy Sci. 96:3401-3413. https://doi.org/10.3168/jds.2012-6074.

Tsioulpas, A., A. S. Grandison, and M. J. Lewis. 2007. Changes in physical properties of bovine milk from the colostrum period to early lactation. J. Dairy Sci. 90:5012-5017. https://doi.org/10 $.3168 /$ jds.2007-0192.

Umaña Sedó, S., D. Rosa, G. Mattioli, R. Luzbel de la Sota, and M. J. Giuliodori. 2018. Associations of subclinical hypocalcemia with fertility in a herd of grazing dairy cows. J. Dairy Sci. 101:10469 10477. https://doi.org/10.3168/jds.2017-14242.

USDA-NAHMS. 2014. Dairy cattle management practices in the United States. National Animal Health Monitoring System (NAHMS).

Valldecabres, A., J. A. A. Pires, and N. Silva-del-Río. 2018. Effect of prophylactic oral calcium supplementation on postpartum mineral status and markers of energy balance of multiparous Jersey cows.
J. Dairy Sci. 101:4460-4472. https://doi.org/10.3168/jds.2017 $-12917$.

Valldecabres, A., J. A. A. Pires, and N. Silva-del-Río. 2019. Cow-level factors associated with subclinical hypocalcemia at calving in multiparous Jersey cows. J. Dairy Sci. 102:8367-8375. https://doi.org/ $10.3168 /$ jds.2018-16180.

Valldecabres, A., and N. Silva-del-Río. 2021a. Association of low serum calcium concentration with productive and reproductive performance in multiparous Jersey cows. J. Dairy Sci. 104:11983-11994. https://doi.org/10.3168/jds.2020-19527.

Valldecabres, A., and N. Silva-del-Río. 2021b. Effects of postpartum oral calcium supplementation on milk yield, milk composition, and reproduction in multiparous Jersey and Jersey $\times$ Holstein crossbreed cows. J. Dairy Sci. 104:795-805. https://doi.org/10.3168/ jds.2020-19079.

Venjakob, P. L., R. Staufenbiel, W. Heuwieser, and S. Borchardt. 2019. Serum calcium dynamics within the first 3 days in milk and the associated risk of acute puerperal metritis. J. Dairy Sci. 102:1142811438. https://doi.org/10.3168/jds.2019-16721.

\section{ORCIDS}

A. Valldecabres (ํ) https://orcid.org/0000-0002-3235-2487

A. Lago @ https://orcid.org/0000-0003-0380-0292

N. Silva-del-Río ๑ https://orcid.org/0000-0002-2826-6797 